\title{
Du, som går ud fra den levende Gud
}

\author{
En fortolkning
}

\author{
Af Peter Balslev-Clausen
}

I

Da N.F.S. Grundtvig i løbet af 1836 - 37 skulle til at realisere sin gamle plan om at samle en "tilstrækkelig Samling af gamle og nye Psalmer " ${ }^{1}$, der skulle indeholde "alle christelige Toner " ${ }^{2}$ fra "de forskelligste Sangskoler i Christenheden ${ }^{3}$, blev han, efterhånden som arbejdet skred frem, stadig mere klar over, at salmerne skulle inddeles efter de 6 hidtidige hovedmenigheder. Ved at lægge dette bibelsk-kirkehistoriske syn, som han havde hentet fra menighedsbrevene i Johannes Åbenbaring kap. 2 og 3, og som han senere fuldt udfoldede i Christenhedens Syvstjerne fra 1854 - 55 (1860), til grund for sit Sang-Vark til den Danske Kirke ønskede Grundtvig dels at give hele kirken mund og mæle, dels at sætte den danske menighed ind i dens Gud-villede sammenhæng.

Den fjerde af hovedmenighederne var efter Johannesåbenbaringens rækkefølge menigheden i Thyatira (kap. 2,18-29), der efter Grundtvigs opfattelse svarede til den angelsaksiske og dermed den engelske menighed. Grundtvig har næppe haft svært ved at genkende sin samtids engelske kirke $\mathrm{i}$ Thyatira-brevets ordlyd. Han lod brevets indhold være bestemmende for sit valg af, hvilke engelske salmer, der skulle oversættes til sangværket, ligesom han lod karakteristiske træk i brevet komme med i oversættelserne.

Langt de fleste af de salmer, der skal repræsentere den fjerde hovedmenighed, stammer fra Grundtvigs egen tid, men han er omhyggelig med at indlede de engelsk-angelsaksiske afsnit med en eller flere angelsaksiske salmer for derved at understrege det moderne Englands sammenhæng med det gamle. Således er pinse-afsnittet, hvorfra "Du, som går ud fra den levende Gud" 
stammer, indledt af "Takker den Herre, som Sorgen omvendte" (nr. 355), der, som Grundtvig skriver i en note, er taget "Af den Angel-Sachsiske Messiade i Exeter-Bogen «.

II

Hedningemissionen var for Grundtvig tæt knyttet sammen med den fjerde menighed. I sit studium af de angelsaksiske skrifter havde han haft kristendommens møde med det nordiske hedenskab i overgangen mellem oldtid og middelalder inde på livet, og i Grundtvigs samtid var det fra England, den store inspiration til hedningemission kom. For den bibellæsende Grundtvig var dette ikke en tilfældighed. Kristus havde i Johannes Åbenbaring kap. 2, v. 26-28 lovet den fjerde menigheds engel "Magt over Hedningerne", dersom han sejrede og til det sidste gjorde hans, Kristi gerninger. Kristus ville dele sin ydre magt med den fjerde menigheds engel: "og han skal regiere dem med et Jern-Spiir; ligesom Leerkar skulle de sønderknuses, som og jeg annammede det af min Fader, " men også den åndelige magt ville Kristus dele med ham, idet han siger, at han "vil give ham Morgenstiernen." Efter 1815 havde Grundtvig set Johannes Åbenbarings ord blive til virkelighed, og gennem sine Englands-ophold 1829 - 31 havde han oplevet denne virkelighed på sin egen krop. Skulle han have en missionssalme med i sit Sang-Værk, måtte den komme fra England.

Grundtvig valgte James Montgomery's $O$ Spirit of the living God fra 1823. Salmens overskrift "The Spirit accompanying the word of God" har uden tvivl været medvirkende til dette valg. For Grundtvig skulle al hedningemission ske gennem forkyndelsen af Guds levende ord; kun det kunne skabe en levende menighed. Derfor var Grundtvig en lidenskabelig modstander af al skole- og bogmission, der lod bibellæsning være det afgørende i missionsarbejdet. I forbindelse med den angelsaksiske forestilling om "Christi Nedfart til Helvede" (sml. den angelsaksiskinspirerede "I Kveld blev der banket på Helvedes Port “4 ${ }^{4}$ gør han $i$ en prædiken af samme navn i Søndags-Bogens 3. bind fra $1831^{5}$ rede for dette syn på hedningemissionen, der går igen flere gange i » $\mathrm{Du}$, som går ud fra den levende Gud». 
The Spirit accompanying the word of God

1. O Spirit of the living God! In all thy plentitude of grace, Where'er the foot of man hath trod, Descend on our apostate race.

2. Give tongues of fire and hearts of love To preach the reconciling word;

Give power and unction from above, Whene'er the joyful sound is heard.

3. Be darkness, at thy coming, light, Confusion order in thy path; Souls without strength inspire with might; Bid mercy triumph over wrath.

4. O Spirit of the Lord! prepare All the round earth her God to meet; Breathe Thou abroad like morning air, Till hearts of stone begin to beat.

5. Baptize the nations; far and nigh, The triumphs of the cross record; The name of Jesus glorify, Till every kindred call Him Lord.

6. God from eternity hath will'd, All flesh shall his salvation see; So be the Father's love fulfill'd, The Saviour's sufferings crown'd, through Thee.

The Christian Psalmist; or, Hymns, selected and original by James Montgomery.

Fourth edition. Glasgow, 1826. nr. 552. 
1. Du, som gaaer ud fra den levende Gud, Aandernes Aand i det Høie!

Menneskens Kiøn mod Guds eenbaarne Søn

Stridende staaer Dig for $\varnothing \mathrm{ie}$,

Men for din Naade, o bliv dog her!

Natten er skummel og den er nær!

2. Tunger af Ild, og dog Prædiken mild,

Giv dem, Du salver og sender!

Saligheds Ord, i Apostlernes Spor,

Vandre til Jorderigs Ender,

Saa ingen Menneske-Fod har rørt

Pletten, hvor ikke dets Røst blev hørt!

3. Glæde og Lys med dem komme tilbyes,

Blomstre lad Muld, hvor de træde!

Styrke og Mod bringe Svaghed paa Fod!

Trøst finde Alle som græde!

Ved Evangeliets milde Røst

Miskundhed vaagne i hvert et Bryst!

4. Skin over Vang, som en Morgen med Sang,

Morgen i Mai naar det grønnes!

Lifligheds Magt giøre Dorskhed opvakt,

Saa paa Guds Naade der skiønnes!

Tonerne dybe i Gry og i Kveld

Røre selv Hjertet, saa haardt som Fjeld!

5. Pindselig Daab, til Guds Herligheds Haab,

Folkefærd alle gienføde!

Tale og Skrift om vor Frelsers Bedrift

Blomstre som Roserne røde!

Livstræet skyde af Korsets Rod!

Smage lad Alle, vor Drot er god! 
6. Saligheds Fryd, for Gienløserens Dyd,

Times lad Mennesker alle!

Faderens Raad og den Hellig-Aands Daad

Sammen i Frelseren falde!

Saa af det Hele, som Gud har skabt,

Gaaer kun Fortabelsens Æt fortabt!

Sang-Verk til den Danske Kirke samlet og læmpet af Nik. Fred. Sev. Grundtvig Præst. Første Bind. Kbh. 1837. Nr. 360. Montgomerys "O Spirit of the Living God" efterlignet.

\section{III}

"Du, som går ud fra den levende Gud " står som nr. 360 i det sidste og største afsnit med ialt 22 oversættelser af engelske (angelsaksiske) salmer i Sang-Værkets forste bind. Grundtvig oplyser i en note, at det er "Montgomerys "O Spirit of the Living God" efterlignet".

En sammenligning mellem Montgomery's original og Grundtvigs oversættelse viser, at Grundtvig på een gang har været loyal og fri i sin oversættelse. ${ }^{6}$ Næsten alle motiver og sammenhænge er kommet med i oversættelsen, men næsten alt er brudt om og ændret, og nyt er kommet til, sådan at Grundtvigs version mere er en gen- og videredigtning end en oversættelse af "O Spirit of the living God". Det er betegnende, at forskelle og tilføjelser i forhold til Montgomery's salme siger mere om Grundtvigs salme end de trods alt mange ligheder med forlægget.

Egentlige tilføjelser $\mathrm{i}$ forhold til den engelske tekst er de to sidste linier i strofe 1 og 6 og de midterste to linier i stroferne 2 og 4 og linie 5 i strofe 3 .

Tilføjelserne understreger dels tilværelsens alvor i spændingsforholdet mellem liv og død, nåde og fortabelse, Gud og Djævel, Himmel og Helvede, dels det levende ords betydning.

Montgomery taler om den frafaldne menneskeslægt ("our apostate race", 1:4), men har ikke Grundtvigs dynamiske dualisme, hvor mennesket ikke kun er frafaldent, men direkte og ak- 
tivt vendt mod Gud: "Menneskens Kiøn mod Guds eenbaarne Søn/Stridende staaer Dig for Øie» (1:3-4). Hos Montgomery er ildtungerne (2:1) nærmest en ekstra inspiration til at prædike det forsonende ord. Hos Grundtvig er tungerne af ild, ordet, røsten, talen, tonerne den guddommelige livskrafts indre dynamik $\mathrm{i}$ Helligåndens komme til verden.

Den mest iøjnefaldende indholdsmæssige ændring fra Montgomery til Grundtvig er, at bønnen til Helligånden i strofe 1 ændres fra "stig ned" til "bliv". For den flittige læser af Johannesevangeliet Grundtvig er der ingen tvivl om, at Helligånden siden den 1. pinse i Jerusalem var i verden, - siger Grundtvig "kom" til Helligånden, er det derfor et "kom" til den, der allerede er i verden -, hvorimod Montgomery forestiller sig, at Helligånden normalt er i Himlen, hvorfra den i modsæetning til Faderen og Sønnen fra tid til anden kan stige ned ("descend ") til verden.

Som den, der er i verden, er Helligånden eet med verden på samme måde som Kristus var det i sin menneskevordelse. Derfor ændres i strofe 4 Helligåndens ydre forhold til verden til et indre, levende forhold. På samme måde i den følgende strofe, hvor det ydre forhold til mennesker hos Montgomery bliver til et indre forhold hos Grundtvig. Disse ændringer bevirker, at hvor man hos Montgomery synger om, synger man hos Grundtvig med Helligånden.

Montgomerys salme består af firliniede strofer, hvor hver linie består af fire jamber. Dette meget enkle versemål ændrer Grundtvig til seksliniede strofer med daktylisk opbygning og vekslende mandlig og kvindelig linieafslutning:

$$
\begin{aligned}
& -\cup \cup-\cup \cup-\cup \cup- \\
& -\cup \cup-\cup \cup-\cup \\
& -\cup \cup-\cup \cup-\cup \cup- \\
& -\cup \cup-\cup \cup-\cup \\
& -\cup \cup-\cup \cup-(\cup) \cup- \\
& -\cup \cup-\cup \cup-(\cup) \cup-
\end{aligned}
$$

Den ens mandlige afslutning på de to sidste linier giver disse to linier karakter af et omkvæd, en konklusion for hver strofe og dermed, sammenlagt, for hele salmen. Taget for sig betegner de 
to sidste linier $\mathrm{i}$ stroferne en stigning $\mathrm{i}$ intensitet fra første til sidste strofe.

Chr. Ludwigs gør opmærksom på, hvordan Grundtvig har fundet frem til versemålet til sin gendigtning af "O Spirit of the living God" ved at kombinere Montgomery's "den levende Gud « med Johannesevangeliet kap. 15,26, hvor der tales om den "Sandheds Aand, som udgaaer fra Faderen", hvorved både salmens anslag og rytme er givet på samme tid. ${ }^{7}$ Salmen igennem vil man kunne se, hvordan de trykstærke stavelser i versemålet overalt svarer til de betydningsbærende ord, sådan at salmens metriske form svarer til dens betydningsmæssige indhold.

På samme måde understreger rimordene salmens indhold, idet de $\mathrm{i}$ de skiftende forbindelser antyder den sammenhæng eller kontrast, der ligger $\mathrm{i}$ indholdet. Rimfølgen er ligesaa levende og markant som versemålet. I 1. og 3. linie er der indrim, sådan at 4. og 10. stavelse rimer på hinanden. 2. og 4. linie har fælles kvindeligt enderim, og de to sidste omkvædslinier har fælles mandligt enderim, hvilket yderligere understreger disse to liniers betydning.

Sammen med versemåls-strukturen har Grundtvig ændret salmens indholdsstruktur. Montgomery's salme består af to halvdele, der er bygget op med en gennemført parallellitet. "O Spirit of the living God!" (1:1) svarer til "O Spirit of the Lord! ..." (4:1), "Give tongues of fire and hearts of love" (2:1) svarer til "Baptize the nations; ..." (5:1), "To preach the reconciling word" (2:2) svarer til "The triumphs of the cross record " $(5: 2)$ og "Souls without strength inspire with might;/Bid mercy triumph over wrath. " (3:3-4) svarer til "So be the Father's love fulfill'd./ The Saviour's sufferings crown'd through Thee. " (6:3-4). På samme måde svarer resten af de to halvdele til hinanden.

Grundtvig bryder denne struktur om og giver i stedet sin salme den V - struktur, der er kendt fra en lang række af hans salmer. ${ }^{8}$ Således svarer stroferne 1 og 6,2 og 5,3 og 4 til hinanden, idet stroferne 1-3 beskriver Helligåndens komme og foreløbige virke og stroferne 4-6 dens fortsatte virke og endelige resultat. Strofe 1 beskriver den verden, Helligånden skal virke i, d.v.s. verden som den er før Helligåndens virke, og som det menneske, der beder til Helligånden, oplever den. Strofe 2 beskriver begyndelsen på Helligåndens gerning, nemlig det leven- 
de Guds-ords komme til verden skildret som menighedens ydre historie. I stroferne 3 og 4 skildres ordets natur. Strofe 5 handler om ordets følger, d.v.s. menighedens indre virkelighed i modsætning til strofe 2 , der skildrer den ydre. Sluttelig beskriver strofe 6 i modsætning til strofe 1 den verden, Helligånden har virket $i$, og som derfor ikke mennesker, som i strofe 1, men Gud har ansvaret for.

Salmen er bygget op over liniepar, $3 \mathrm{i}$ hver strofe, som den mindste strukturelle indholdsenhed. Således er det også ordparrene, der svarer til hinanden i V - strukturen. 1:1-2 svarer til 6:34, 1:3-4 svarer til 6:1-2 og 1:5-6 svarer til 6:5-6, og så fremdeles, idet parallelliteten i de øvrige strofer er endnu mere gennemført, sådan at det er de tilsvarende linier i de parallelle vers, der svarer til hinanden. Den asymetriske parallellitet mellem linieparrene i strofe 1 og 6 skyldes den indledende tiltale i strofe 1 .

I strofe 1 tiltales først den guddommelige virkelighed $i$ den menneskelige verden, Helligånden. Derefter omtales den menneskelige virkelighed, som den er uden erkendelsen af det guddommelige, og endelig nævnes det menneskelige behov for erkendelse af og samfund med det guddommelige, som Helligånden er i stand til at imødekomme. De følgende fire strofer, der alle handler om Helligåndens gerning i det levende ord, er bygget op over en tredelt struktur, der for hver strofe svarer til V strukturen for hele salmen, idet de tre liniepar beskriver henholdsvis ordets forkyndelse, virke og tilegnelse. Som nævnt handler strofe 2 om den kirkehistoriske sammenhæng, idet der i linie 1-2 tales om ordets forkyndelse, sådan som den fandt sted den 1. pinsedag i Jerusalem; i linierne 3-4 tales der om ordets udbredelse over hele verden, og i linierne 5-6 om tilegnelsen af ordet overalt, hvor der er mennesker, der kan høre det. I stroferne 3 og 4 handler linierne 1-2 i begge strofer om, at ordet bringer lys, linierne 3-4 om, at det bringer liv, og linierne 5-6 om, at det bringer salighed til mennesker. Strofe 5 , der handler om menighedens indre virkelighed, beskriver ordets sakramentale sammenhæng, først, linierne 1-2, dåben som ordets komme til menigheden, derefter, 1. 3-4, i ordet selv og dets virkning, og endelig, 1. 5-6, i nadveren, der er menighedens endelige tilegnelse af ordet. I alle fire strofer er det vigtigt at huske, at det levende ord, der er Helligåndens fremtrædelsesform, for Grundtvig hænger 
nøje sammen med Johannesevangeliets indledende beskrivelse af Jesus Kristus som Guds ord. Dette har betydning i strofe 6, hvor det i modsætning til de foregående strofer ikke er Helligånden, men Kristus, eller, som han kaldes, "Gienløseren " og "Frelseren ", der er den centrale skikkelse, både i menigheden (1. 1-2) og i Treenigheden (1. 3-4), ligesom det er dem, der i dåben er genfødt og vokset op sammen med ham, der er modstykket til "Fortabelsens Æt “ (1. 5-6). Iøvrigt er strofe 6 ligesom trosbekendelsen set bagfra i dens menighedsmæssige sammenhæng: 1. 1-2 svarer til kristenlivet her og hisset (associationsord hertil er henholdsvis "times" og "Salighed "), 1. 3-4 svarer til trosbekendelsen og 1. 5-6 til forsagelsen.

\section{IV}

Grundtvig må have skrevet sine oversættelser af de engelske pinsesalmer nogenlunde ud $\mathrm{i}$ et stræk $\mathrm{i}$ foråret og forsommeren 1837. Det er derfor naturligt, at der er en række motivsammenfald fra salme til salme. Især er det de umiddelbart foregående salmer fra nr. 355 i Sang-Værket, "Takker den Herre, som Sorgen omvendte", der har motiver fælles med "Du, som går ud fra den levende Gud."

Det truende mørke og natten i slutningen af strofe 1 er et gennemgående motiv i de fem foregående salmer. Natten står $\mathrm{i}$ "Takker den Herre, som Sorgen omvendte" i forbindelse med "Fienderne" (355.6:3-7:2). I "Gud-Helligaand! o kom" opfattes syñden som et mørke, der skal lyses op af Helligånden (356.2:1), ligesom der i "Hellig-Aand! vor Sorg Du slukke! " tales om, at Helligånden skal gøre "Al vor Dunkelhed ... klar» (357.1:2). Tilsvarende bliver Helligånden i "Fordum Alt var tomt og øde" bedt om at "Vække Liv med Lys og Styrke,/Hvor kun før var Død og Mørke“ (359.4:5-6).

På baggrund af det syndens og dødens mørke, der omslutter mennesker i denne verden, er pinsedagen med dens begivenheder som en ny skabelsesmorgen, hvor Gud med sit ord sætter skel mellem lys og mørke, mellem liv og død, tro og vantro. Gennem ordet, der med Helligånden kom til disciplene som flammende ild, blev både på kort sigt, på selve pinsedagen, og på 
langt sigt, i løbet af kirkens historie, en ny menneskehed, et nyt gudsfolk skabt. Derfor kan Grundtvig sige, at da Gud sendte sin Helligånd til verden, "et Lys Han til Nætterne tændte,/Tungernes Flamme og Hjerternes Glød!“ (355.6:3-4), og han kan i »Hellig-Aand! med Velbehag " sige "Tændte af din Lue mild,/Lad os tale Sandt med Ild!« (358.2:5-6). I forlængelse af pinsedagens "Tunger af Ild " (2:1) er Grundtvig sikker på, at "Trøst finde Alle, som græde! “ (3:4), når han beder Helligånden, "Trøster i al Nød ", om "Lys for Mørke, Liv for Død!“ (357.1:5-6).

Det er det samme lys, der går igen i strofe 4 , hvor pinsetidens forsommersol bliver et billede på, eller en erindring om, lyset og herligheden i Guds rige, sådan som mennesker, - Adam og Eva -, kunne opleve det på skabelsens morgen i Paradisets have, før "Mai-Lærkeslaget i Paradis-Vang " var endt med syndefaldet (355.1:3-4). De to sidste linier af strofe 4 har ligeledes motiver tilfælles med "Takker den Herre, som Sorgen omvendte", hvor der i strofe 4 tales om "Dagning og Kveld " (4:2) og i strofe 6 om "Tungernes Flamme og Hjerternes Glød " (se ovenfor), idet Helligåndens ildtunger også her sættes $\mathrm{i}$ modsætning til verdens nattemørke.

I strofe 5 sættes Helligånden og dåben i forbindelse med hinanden. Dåben er som i "Herren strækker ud sin Arm " genfødelsens bad af liv til liv (368:5-6), og Helligånden er "HimmelBarnlighedens Aand " (358.3:1), idet den kristne fødes, vokser op, dør og bliver oprejst fra de døde sammen med Kristus, sådan som det beskrives i strofe 5 og begyndelsen af strofe 6 (5:1-6:2).

Også i andre salmer sættes "Gienløserens Dyd" (6:1) og "Saligheds Fryd " $\mathrm{i}$ forbindelse med Helligånden, der i "Fordum Alt var tomt og øde" erhverves som "Guds Aand med SkaberMagt " ved "Jesu Dyd " (359.3:3-4) for igen at skabe lys og liv i det menneske, der er fordærvet og ødelagt. Også her er skabelsens spænding mellem liv og død, lys og mørke rammen for Helligåndens gerning. I samme forbindelse siger Grundtvig i "Takker den Herre ..." til den kristne, at "Aand er din Fader, til Aand skal du blive,/Engle til Glæde og Fiender til Trods" (355.3:1-2). Helligånden er, som antydet her, menneskets værn mod Djævelen, Guds og menneskers fjende. Uden Helligånden som forbundsfælle, "var vor Fred forbi,/Og vi blev Fiendens Bytte! « (356.6:3-4). Mennesket står i verden i den stadige spæn- 
ding mellem skabelse og fortabelse, liv og død, Gud og Djævel, og Helligånden er menneskers pant på, at fremtiden tilhører Gud, skabelsen og det nye liv og ikke Djævelen, fortabelsen, døden. Derfor kan Grundtvig sige til Helligånden i "Helligaand! vor Sorg Du slukke«:

$\mathrm{Du}$, den nye Verdens Skaber!

Viis i os, hvad Du formaaer!

Kæmp, saa Verdens Fyrste taber!

Kæmp, saa Christi Kirke staaer!

Grundtvig anslår $\mathrm{i}$ den oprindelig angelsaksiske "Takker den Herre, som Sorgen omvendte" (355) de motiver, der derefter bliver bearbejdet med forskelligt udgangspunkt $\mathrm{i}$ de følgende gendigtninger af moderne engelske salmer. I "Du, som gaaer ud fra den levende Gud " (360) făr disse motiver deres afrundende behandling med Helligånden som den Guds-kæmper, der sikrer lysets sejr over mørket og dermed Guds sejr over Djæevelen.

I forlængelse af den angelsaksiske livsopfattelse ligger Grundtvigs almindelige dualistiske livsforståelse, sådan som han et halvt års tid $\mathrm{i}$ forvejen havde givet udtryk for den i sin samtale med professor Marheineke fra Berlin, der var i København i anledning af det danske reformationsjubilæum: "For mig er Hovedmodsætningen Modsætningen mellem Liv og Død «". Grundtvig arbejder til stadighed med denne modsætning, der er en af grundstrukturerne $\mathrm{i}$ hans digtning, ikke mindst $\mathrm{i}$ hans salmedigtning. Et eksempel på, hvordan modsætningen mellem liv og død kan sættes skematisk, nærmest symmetrisk op er strofe $1 \mathrm{i}$ "Tag det sorte Kors fra Graven" (Sang-Værket nr. 302), hvor livs- og dødsordene linie for linie er stillet op lige overfor hinanden. ${ }^{10}$

"Du, som går ud fra den levende Gud " er ikke alene skrevet $\mathrm{i}$ spændingen mellem "den levende Gud" i den første og "Fortabelsens Æt" i den sidste linie i salmen. Hele vejen igennem er spændingen til stede som menneskets, - det kristne menneskes -, vilkår $\mathrm{i}$ verden $\mathrm{og}$ som den modstand, Helligånden skal overvinde.

Livs- og døds-modsætningen og dens ord i salmen bruges 
ikke alene til at trække de store linier op med, den bruges også i en mere detaljeret karakteristik som i stroferne 3 og 4 , hvor ordets natur skal skildres. Her er næsten hver sætning, d.v.s. linie eller liniepar, bygget op over spændingen mellem livs- og dødsordene, der igen er ord for Himmel og jord, Gud og Djævel. Således står i strofe 3 "Glæde" og "Lys" overfor "tilbyes ", idet 'byen' her svarer til den græske 'polis', den verden, der er beboet af mennesker ${ }^{11}$; i næste linie står "Blomstre" overfor "Muld", derefter "Styrke" og "Mod" overfor "Svaghed", og "Trøst" overfor "græde«. På samme måde i strofe 4, hvor livsordene "Skin", "Morgen ", "Sang", "Morgen", "Mai" og "grønnes " står overfor "Vang ", der som denne verden svarer til "tilbyes" og "Muld" i strofe 3. I linie 3 og 4 står "Lifligheds Magt", "opvakt" og "Guds Naade" overfor "Dorskhed ". I de to sidste linier i strofen har Grundtvig dødens mørke ("Kveld ") og hårdhed ("haardt som Fjeld ") i tankerne i deres modsætning til livets lys ("Gry") og levende blødhed og modtagelighed, som hjertet trods sin tilsyneladende hårdhed er et billede på. Begge strofer igennem er det Grundtvigs tanke, at Guds ord skaber liv, hvor det møder den verden, der uden det er dødsmærket.

Dette skabelsesmotiv, hvor ordet skaber, hvad det nævner, er ligeledes baggrunden for den indledende og afsluttende modsætning. I strofe 1 nævnes mørket, det mørke, der rugede over verden, før Gud på skabelsens første dag sagde, at der skülle blive lys, og der blev lys, og lyset trængte mørket tilbage. Derefter er lyset et af hovedmotiverne i de følgende tre strofer, og endelig siger Grundtvig til sidst i strofe 6, at "Så af det hele, som Gud har skabt (!),/Går kun Fortabelsens Æt fortabt!« (6:5-6). Guds skabelse går gennem hele verden, fra begyndelsen til enden, og først når verdens historie slutter, slutter også beretningen om dens skabelse. Indtil da begynder hver dag med et guddommeligt "Bliv lys", og der bliver lys, i direkte og i overført betydning.

Teologisk beskriver Grundtvig den fortsatte skabelse med begrebet genfødsel (5:2), der finder sin logiske fortsættelse i tanken om den endelige genløsning (6:1). Herved sætter Grundtvig sit skabelsessyn ind $i$ en traditionel teologisk sammenhæng, mest markant i strofe 6, hvor først den objektive forsoningslære, der- 
efter den økonomiske trinitetslære og til sidst den traditionelle eskatologi beskrives så kort og klart som næppe nogetsteds i den teologiske litteratur.

Iøvrigt er det interessant at se, hvordan Grundtvig lader den teologiske udvikling i de fire forste linier i strofe 6 være forudsætningen for udsagnet $i$ de to sidste linier. Hertil svarer, at "Saa" ifølge versemålet skal udtales med tryk og derved udtrykke årsagssammenhængen: Således kan det ske, at det hele o.s.v.

Salmens verbalstruktur svarer til det billede, der her er givet af salmens formelle og indholdsmæssige struktur. I modsætning til Montgomery's "O Spirit of the living God ", hvor alle verber er i imperativ, hvorved salmens karakter af bøn understreges, begynder og slutter Grundtvigs salme med indikativ svarende til salmens grundstruktur. I strofe 1 beskriver indikativerne udgangspositionen, det guddommelige lys og liv på den ene side og på den anden side den menneskelige bundethed af mørket og døden, også i forhold til Gud. I de følgende strofer gælder indikativerne, bortset fra en tilfældig relativsætning i strofe 3, de udsagn, der beskriver Guds skabelses- og genløsningsvilje, nemlig 2:5-6, 4:4 og 6:5-6, alle udsagn, der indledes med "saa" (se ovenfor), og alle udsagn, der enten er taget ud af deres sammenhæng hos Montgomery (som 2:5) eller er Grundtvigs egne (som 4:4 og 6:5-6).

Herved deles salmen op i 4 afsnit. Et indledende, der beskriver genfødselens og genløsningens udgangsposition, såvel den positive (guddommelige) som den negative (menneskelige). Derefter beskrives i stroferne 2 og 3 omkring den første "saa "-sætning Guds vilje til, at hans ord skal høres (d.v.s. viljen til Helligåndens gerning). I stroferne 4 og 5 skildres omkring den anden "saa"sætning ordets (Helligåndens gernings) virkning, og endelig handler den afsluttende strofe 6 om resultatet af ordets, Helligåndens virkning, d.v.s. den endelige genløsning, eller den genfødsel, der i et eskatologisk perspektiv fører over i skabelsen af en ny himmel og en ny jord. Bortset fra de nævnte indikativer er salmens verber $i$ imperativ eller optativ og udtrykker derved den bøn, der som sin baggrund og forudsætning har den virkelighed, som indikativerne beskriver. 
$\mathrm{V}$

Som allerede nævnt skylder Grundtvigs gendigtning af "O Spirit of the living God " rytmen i to skriftsteder sit versemål. I virkeligheden er hele Grundtvigs salme gennemvævet med skriftsteder. Efter at have peget på en række skriftsteder som Grundtvigs direkte inspiration ved gendigtningen af Montgomery's salme, ${ }^{12}$ gør Ludwigs opmærksom på den stadig uløste opgave at undersøge Grundtvigs brug af og bundethed til Bibelen i Sang-Værket. ${ }^{13}$ Anders Malling henviser til Ludwigs ${ }^{14}$ og nævner forskellige skriftsteder uden at give nogen endelig behandling af spørgsmålet.

Det er uden tvivl Montgomery's brug af Daniels beskrivelse af Gud som den "levende Gud " (Dan. 6,27), der har fanget Grundtvigs interesse, og efter kombinationen med Johannes 15,26, "den Sandheds Aand, som udgaaer fra Faderen " (se nedenfor), har den gammeltestamentligt klingende fortsættelse "Aandernes Aand i det Høie" givet sig af sig selv. Derefter har Grundtvig, idet han er forblevet i den gammeltestamentlige tankegang, taget Esaias' ord om israelitterne, at de var "gienstridige og bedrøvede hans Hellig Aand; derfor omvendtes han for dem til en Fiende" (Es. 63,10), hvorefter han afslutter strofen med en henvisning til de to mænds ord til Jesus i Emmaus om at blive hos dem, "thi det er mod Aften, og Dagen helder" (Luk. 24,39), eventuelt tænkt sammen med Jesu ord fra Johannesevangeliet 9,4: "Mig bør det at giøre hans Gierninger, som mig haver udsendt, saalænge det er Dag; Natten kommer, da Ingen kan arbeide«, overført på Helligånden.

I Sang-Værkets 2. udgave fra 1868 har Grundtvig ændret strofens to midterste linier til "Løgnerens Æt, som giør Talsmanden træt,/Staaer Dig gienstridig for Øie«. Herved skiftes Esaias 63,10 ud med Johannesevangeliet 8,44, hvor Jesus siger til sine tilhørere, efter at de har henvist til, at de er Abrahams slægt: "I ere af en Fader, Diævelen, og ville giøre Eders Faders Begieringer. Han var en Manddraber fra Begyndelsen af, og blev ikke bestaaende i Sandheden; thi Sandhed er ikke i ham. Naar han taler Løgn, taler han af sit eget; thi han er en Løgner, og Løgnens Fader. «

Gennem denne ændring i 2.-udgaven træder sammenhængen i strofe 1 tydeligere frem. Dels præciseres det, at menneskers 
modsætning til Gud, her Helligånden, i virkeligheden er Løgnerens, Djævelens modsætning til ham. Dels træder det klarere frem, at Grundtvig med sin beskrivelse af "Menneskens Kiøn" ikke alene tænker på mennesker $\mathrm{i}$ almindelighed, men at han $\mathrm{i}$ særdeleshed tænker på sine rationalistiske samtidige, der mente om sig selv, at de var lysets og sandhedens talsmænd, ligesom jøderne på Jesu tid sagde om sig selv, at de var Abrahams slægt ("Jeg veed, at I ere Abrahams Sæd ", Johs. 8,37-41), selvom de i virkeligheden, både rationalisterne og jøderne, var "Løgnerens Æt». Samtidig gør omtalen af "Løgneren" hentydningen her som i strofe 6 til forsagelsen og trosbekendelsen tydeligere, og for dem, der forstod at høre efter, ikke alene. mere nærværende, men også mere kontroversiel.

Strofe 2 er en kombination af beretningen om, hvordan Helligånden pinsedag $\mathrm{i}$ Jerusalem kom til disciplene i form af ildtunger, og hvordan disciplene derefter kunne forkynde Guds ord på alle tungemål, sådan som det fortælles i Apostlenes Gerninger kap. 2, og om, hvordan Jesus kort forinden havde sagt til dem, at de skulle være hans vidner i Jerusalem, Judæa, Samaria, "og indtil Jordens Ende" (Ap.Ger. 1,8). Samtidig refererer strofen til Romerbrevets kap. 10,18: "Jo sandelig! deres Røst er udgangen over al Jorden, og deres Ord til Jorderigs Grændser", der igen er et citat fra Salme 19,5: "Deres Maalesnor er udgangen over al Jorden, og deres Taler til Jorderiges Ender. «

Kombinationen "Prædiken mild " med "Menneske-Fod" kan Grundtvig have fra samme kap. 10 i Romerbrevet, hvor Salme 19 er citeret, idet der lidt tidligere, v. $14-15$ med henvisning til Esaias 52,7 står: "Hvorledes skulle de vel paakalde den, paa hvem de ikke have troet? men hvorledes skulle de troe paa den, om hvem de ikke have hørt? men hvorledes skulle de høre, uden der er Nogen, som prædiker? Men hvorledes skal Nogen prædike, dersom de ikke blive udsendte? Som skrevet er: Hvor deilige ere deres Fødder, som forkynde Fred, som forkynde godt Budskab! « Billedet med "deres Fødder, som forkynde Fred " skyldes Grundtvigs association fra Montgomery's "Where'er the foot of man hath trod", der i Grundtvigs gendigtning, "Saa ingen Menneske-Fod har rørt/Pletten, hvor ikke dets Røst blev hørt! « forudsætter det gammeltestamentlige billede, som allerede Paulus har lånt fra Esaias. Grundtvig er som salmedigter i vid udstræk- 
ning præget af bibelske associationer, også hvor forlægget ikke direkte lægger op til dem.

Igen i strofe 5 er der bibelske associationer. Den pinselige dåb fra Apostlenes Gerninger kap. 2 sættes sammen med "Guds Herligheds Haab", der stammer fra Romerbrevet kap. 5,2: "... og vi rose os af Haab om Herlighed hos Gud ". Sammenstillingen af den pinselige dåb og alle folkefærd stammer bortset fra Apostlenes Gerninger kap. 2 fra kap. 10,45-47, hvor det fortælles om dem, der var sammen med Peter hos høvedsmanden Cornelius i Cæsarea, at de blev ude af sig selv af undren over, "at den Hellig Aands Gave blev udøst over Hedningerne. Thi de hørte dem tale med fremmede Tungemaal og prise Gud. Da svarede Petrus: mon nogen kan formene Vandet, at disse ikke skulle døbes, som have annammet den Hellig Aand, ligesom og vi?".

Genfødelsens hovedsted er Jesu samtale med Nicodemus i Johannesevangeliet kap. 3, hvor Jesus siger til Nicodemus, at "uden nogen bliver født paa ny, kan han ikke see Guds Rige", (v. 3) og hvor han lidt senere tilføjer, at denne genfødsel skal ske "af Vand og Aand ", (v. 5) hvilket sidste passer med, at de to første linier i strofe 5 handler om dåben. Ifølge 1. Petersbrev kap. 1,23 skal genfødslen ske "ved Guds Ord, som lever og bliver evindeligen." Det var dette ord, der lød på pinsedagen (2:1), hvor menneskeheden blev genfødt (5:1-2), ligesom menneskenaturen var blevet genfødt, da Kristus, Guds ord, kom til verden (Johs. $1,1 \mathrm{ff})$. I denne sammenhæng bliver Kristus den anden Adam og korset bliver livets træ fra Paradisets have (1.Mos 2,9). Ligesom Adams fald spærrede vejen til livets træ og var årsag til, at døden kom ind i verden, har Kristi død og opstandelse åbnet vejen til livets træ igen og påny bragt livet ind $\mathrm{i}$ verden.

Den sidste linie i strofe 5, "Smage lad Alle, vor Drot er god!" er næsten ordret taget fra Salme 34, vers 4: "Smager og seer, at Herren er god; salig er den Mand, som troer paa ham ", idet 2. halvvers leder videre til linie 1 i strofe 6: "Saligheds Fryd for Gienløserens Dyd“. Der er her tale om nadveren og om, at Grundtvig sammentænker de to motiver, livstræets frugter og Kristi legeme og blod, der her blivet eet, hvorved verdens genskabelse eller genfødsel i Kristus bliver den positive gentagelse af den første skabnings indhold.

Motiverne fra de to sidste linier i strofe 5 samles i Kristi ord til 
menigheden i Efesus (Johs. Âbenbaring 2,7) om, at "den, som seirer, ham vil jeg give at æde af Livsens Træ, som er midt i Guds Paradiis." Det er næppe tilfældigt, at Grundtvig hæfter sig ved dette skriftsted. Efesus-menigheden repræsenterer for ham hebræer-menigheden, der i sig rummer spændingen mellem den første og den anden Adam, Livets træ i Paradisets Have og Jesu Kors, livstræets frugt og Jesu legeme og blod. Samtidig med, at billedet i sig rummer spændingen mellem skabelse og genfødsel, rummer det også perspektivet frem mod den endelige genløsning, det eskatologiske perspektiv, da det livstræ, der skyder af korsets rod, først for alvor bærer sine frugter i Guds rige (sml. Matth. 26,29). Denne forståelse af billedet har Grundtvig fundet hos de gamle angelsaksere, der i forlængelse af den oldkirkelige tradition satte livstræet i Paradis og Jesu kors på Golgata i forbindelse med hinanden, de opfattede dem så at sige som to alen af eet stykke og så dem iøvrigt, som Grundtvig gør det her, i et eskatologisk perspektiv. ${ }^{15}$ Grundtvigs angelsaksiske associationer $\mathrm{i}$ denne sammenhæng ses også af betegnelsen "Drot " for Kristus. For angelsakserne var Kristus drotten, helten, hvis bedrift det var at gå i døden for sit folk. Også roserne i linie 4 ("Roserne røde") understreger forbindelsen mellem livstræet og korset, Paradis og Golgata, da roserne efter oldkirkelig opfattelse dels hørte hjemme i Paradisets have, dels var et symbol på martyrernes blod. ${ }^{16}$

Betegnelsen "Gienløser" for Kristus har Grundtvig fra Esaias 43,1, hvor perspektivet er Israels skabelse - genskabelse, eller fødsel - genfødsel: "Men nu siger Herren saaledes, som skabte dig, Jakob! og dannede dig, Israel! frygt ikke, thi jeg gienløste dig, jeg kaldte dig ved dit Navn, du er min. "Dette svarer $i$ kristologisk perspektiv til Jesu ord i Johannesevangeliet 6,39: "Men dette er Faderens Villie, som mig udsendte, at jeg skal intet miste af alt det, som han haver givet mig; men jeg skal opreise det paa den yderste Dag. ", sammenlign med Jakobsbrevet 1,18: "Efter sit Raad fødte han os formedelst Sandheds Ord, at vi skulde være en Førstegrøde af hans Skabninger. " Herfra går Grundtvigs associationer videre fra "Beslutning " til "Villie" og "Raad" (6:3), sådan som det siges i Efeserbrevet 1,9-11, hvor tanken om Guds "Huusholdning " med verden nævnes, og forestillingen om den økonomiske Treenighed derfor ligger nær: "i 
det han kundgiorde os sin Villies Hemmelighed, efter den velbehagelige Beslutning, hvilken han forud fattede hos sig selv, at oprette en Huusholdning i Tidernes Fylde, for at samle Alt under eet Hoved udi Christo, baade det, som er i Himlene, og paa Jorden, udi ham; i hvem ogsaa vi have faaet Lod, vi, som forud vare bestemte efter hans Beslutning, som virker Alt efter sin Villies Raad." Dette sted kan suppleres med 1. Timoteus-brev 2,4, hvor der tales om Gud, vor Frelser, "som vil, at alle Mennesker skulle blive salige, og komme til Sandheds Erkiendelse."

De sidste to linier i strofe 6 har deres baggrund i Johannesevangeliets kap. 16 og 17, hvor Jesus siger, at når Talsmanden, Helligånden kommer, "skal han overbevise Verden om Synd, og om Retfærdighed, og om Dom: Om Synd, fordi de troe ikke paa mig. Men om Retfærdighed, fordi jeg gaaer hen til min Fader, og I see mig ikke længere. Men om Dom, fordi denne Verdens Fyrste er dømt " (Johs. 16,8-11). Overfører man dette skema på "Du, som går ud fra den levende Gud", ser man, at den "Synd", Jesus taler om, svarer til strofe 1, der handler om modstanden mod Kristus, "Retfærdigheden " svarer til strofe 2-5, der handler om den verden, Kristus har forladt, og hvor Helligånden og med den ordet virker, indtil den genfødsel og genskabelse, d.v.s. det fornyede liv i Kristus, der antydes i strofe 5, indtræder, og "Dom" svarer til strofe 6. "Fortabelsens Æt" svarer altså som udtryk til, at Jesus i Johannesevangeliet 17,12 kalder Judas Iskariot "det Fortabelsens Barn" sml. Johs. 8,44, der er citeret ovenfor $\mathrm{i}$ forbindelse med strofe 1 , og hvor Jesus taler om Djævelen som "en Løgner, og Løgnens Fader."

\section{VI}

Grundtvigs bibelbrug havde sin faste forankring $\mathrm{i}$ hans dagligdag. Der var ikke tale om mere eller mindre tilfældige læsefrugter, der levede deres eget liv i hans forestillingsverden. Grundtvig var præst og prædikant og dermed bundet til Bibelen gennem ritualer og prædiketekster. Denne livssammenhæng med de bibelske tekster viser sig i høj grad i hans salmedigtning, således også i "Du, som går ud fra den levende Gud «. Sammenhængen viser sig derved, at de prædiketekster (på Grundtvigs tid var 
epistelteksterne ligeså fuldt prædiketekster som evangelieteksterne), der ligger bag salmens ordlyd alle stammer fra tiden fra Påske til lige efter Pinse, nogenlunde den tid, Grundtvig må have arbejdet med de engelske pinsesalmer i Sang-Værket, deriblandt "Du, som går ud fra den levende Gud".

Johannesevangeliet 15,26 om "Sandheds Aand, som udgaaer fra Faderen", der sammen med "den levende Gud " fra Montgomery's salme har givet Grundtvig rytmen til versemålet, hører til 6. søndag efter Påske (i 1837 d. 7. maj). Johs. 16,8-9 der ligger bag både strofe 1 og 6, og som danner baggrund for Grundtvigs strukturering af salmen, hører til 4. søndag efter Påske (d. 23 april). Slutningen af strofe 1 er hentet fra evangeliet til 2. Påskedag (27. marts) (Luk. 24,29), hvorfra Grundtvig har både nattemotivet i strofe 1 og nadvermotivet i strofe 5 , der foregribes her.

Strofe 2 henter sine motiver fra pinseberetningen 1. Pinsedag (d. 14. maj) (Apostlenes Gerninger 2,3 ff) og fra Kristi Himmelfartsdag (d. 4. maj) (Ap. Ger. 1,8). I strofe 5 stammer tanken om hedningefolkenes dåb fra en kombination af epistlerne til 1. og 2 . Pinsedag (d. 14. og 15. maj) (Ap. Ger. 10,45 ff) og tanken om genfødslen stammer fra evangeliet til Trinitatis Søndag (d. 21. maj) om Jesu samtale med Nikodemus (Johs. 3,3-5). Fortabelsens mulighed i slutningen af strofe 6 er inspireret af evangeliet til 1. søndag efter Trinitatis (d. 28. maj), der handler om Den rige mand og Lazarus (Luk. 16,19-31).

\section{VII}

Går man fra prædiketeksterne til selve prædikenerne, vil man se, at Grundtvig i høj grad her beskæftiger sig med de samme spørgsmål som i "Du, som går ud fra den levende Gud «. Det er påfaldende, at der ikke uden videre er sammenfald mellem selve teksternes betydning for salmen og behandlingen af salmens motiver i prædikenerne. Denne asymetri skyldes uden tvivl, at Grundtvig husker de tekster, han har brug for i sit salmearbejde, hvorefter han bruger dem uafhængigt af den situation, prædikenerne over dem var holdt i og ud fra, hvorimod han i de prædikener, der var samtidige med salmearbejdet, behandler de samme motiver både i salmen og i prædikenerne. 
Grundtvig kommer 1. søndag efter Påske (d. 2. april) ${ }^{15}$ ganske kort ind på det grundspørgsmål, som han også behandler i "Du, som går ud fra den levende Gud «: "i Christi Kirke», skriver han (s. 3), "saavelsom derudenfor, er det Menneske-Hjertets store Spørgsmaal, om der er Trøst over Synden og Raad imod Døden."

I Kristi Himmelfartsprædikenen kommer Grundtvig ind på spørgsmålet om menneskets og verdens plads i spændingen mellem liv og død, Gud og Djævelen. Denne spænding er et grundvilkår for den menneskelige tilværelse. Han refererer den udbredte tilbøjelighed hos "Verdens Digtere og Grublere», d.v.s. tilhængerne af den romantiske enheds- og identitetstænkning, til at "forkynde, at ikke blot Himmel og Jord, men Himmel og Helvede skal tilsidst sammensmelte", idet ikke alene Gud og mennesker, men også Gud og Djævel, Ånd og kød, sandhed og løgn bliver eet. En sådan opfattelse må Grundtvig afvise både af teologiske (opfattelsen er i Helvede i det mindste "langt behageligere end Aabenbaringen af Guds Villies Hemmeligheder i Christo Jesu ") og af filosofiske (sandhed og løgn kan logisk set ikke forenes) grunde.

1. Pinsedag kommer Grundtvig efter en kort omtale af sprogunderet $\mathrm{i}$ Jerusalem ind på, at mennesket, ikke alene det menneske, der kender Gud gennem Israels historie, men også hedningerne har en bevidsthed om, at "Mennesket oprindelig er i Slægt med sin Skaber« (s. 1), der, dengang han blæste livsånde i det, gav det evnen til at tale og lagde det ordet i munden. Mennesket faldt, men det "behagede vor Himmelske Fader at opreise, gienføde, fornye, velsigne og forklare" den "dybt faldne og fordærvede Menneske-Natur", sådan som det skete i Jesus Kristus. Som (- fordi -) Jesus Kristus var Gud og menneske, har kristendommen både en guddommelig og en menneskelig side, og det er først og fremmest den menneskelige side, "Menneske-Ligheden", der skal genfødes, "det ny Menneske, der skal fødes og opvoxe paa Jorden til vor Herres Jesu Christi Ære" Det er en hovedopgave for Helligånden at sørge for, at det sker (s. 3).

Lidt senere (s. 5) slår Grundtvig fast, at Helligåndens virke ikke kun gælder "et enkelt Folk, men ... alle Folkefærd under Himlen ". Helligånden har universel betydning og er hævet "høit over alle Folke-Aander", da den er "hele Menneske-Slægtens Aand den Livs-Aande, Gud indblæste Adam." Var Helligånden 
med ved menneskets skabelse, skal den også være det ved menneskets genskabelse. At det er tilfældet, kan ses af den glade lovprisning (- salmesangen -) i kirkerne og "af den glade Forventning om Hans Herligheds Aabenbarelse" (s. 6), der her som i strofe 5:1-2 skal ses i forbindelse med alle folkefærds genfødsel. Sidst i prædikenen (s. 8) kommer Grundtvig ind på "den HelligAands Daad" (strofe 6:3), der er "at tale det evige Livs Ord", hvorved Helligånden beviser, at "Han er intet ringere end Guddommens Aand, som virker alle Ting i Alle! " hvilket først og fremmest er at råde bod på "Jordens Møie» og "vore naturlige Plage-Aander", d.v.s. "Synden og Døden", og dernæst "virkelig og varig, kraftig og kiærlig [at] forbinde os med Himlen og Evigheden."

Efter at have prædiket om de gudelige forsamlinger 2. Pinsedag, vender Grundtvig Trinitatis Søndag tilbage til motiver, som han også arbejder med i "Du, som går ud fra den levende Gud." Udfra evangeliet om Jesu samtale med Nikodemus er det især spørgsmålet om dåb og genfødsel, han kommer ind på. Dåb og genfødsel hører for Grundtvig uløseligt sammen som den enkeltes "Indtrædelse i Aandens Verden og ... den eneste Dør til Guds Huus baade her og hisset " (s. 2). Genfødslen er ikke alt muligt andet, sådan som nogle har villet mene. Den, der ikke tror, at dåben som genfødsel af vand og Ånd er Kristi indstiftelse, indgår ikke til det evige liv, men går fortabt (s. 5). Et problem ved forståelsen af forholdet mellem dåb og genfødsel har været mangelfuld oplysning om, hvad genfødslen egentlig betyder. "Man havde nemlig vænt sig til at betragte Gienløsning og Gienfødelse, Fornyelse og Helliggiørelse omtrent som Eet og det Samme, saa Alt hvad der gjaldt om det Ene, gjaldt ogsaa om det Andet, uden at det gjorde nogen Forskiel hvormed man begyndte" (s. 5 f). Genfødslen i dåben er menneskelivets fornyelse. Fødslen er forudsætningen for det efterfølgende liv, og genfødslen er det samme "i aandelig Forstand, som den naturlige Fødsel er i Kiødelig, saa ligesom vi fødtes af Kiød til Kiød maa vi ogsaa fødes af Aand til Aand " (s. 7). Grundtvig sammenligner videre genfødslen med "Vaaren i det Legemlige" (prædikenen er skrevet til d. 21. maj), "thi med den kan Gienfødelsen bedst sammenlignes, da begge Dele er en Slags Fødsel men tillige en Opstandelse af Noget i Grunden født for længe siden, men lagt som dødt i 
Vinter-Dvale“ (s. 8), og han sætter dette billede ind i en bibelsk sammenhæng ved at anbringe genfødslen i spændingen mellem på den ene side Paradis - med livstræet - og den første Adam, og på den anden side Guds rige og den anden Adam (sml. ovenfor): "thi hvem skulle ikke længes efter en Vaar i Guds Rige, da først det Jordiske Paradis med den første Adam og derpaa det Himmelske med den anden Adam liver op for vore Øine og for vort Hjerte!“ (s. 8). Der er her tale om en tankegang, der går helt parallelt med tankegangen $\mathrm{i}$ " $\mathrm{Du}$, som går ud fra den levende Gud «. Om det så er forårsmotivet i stroferne 3-5 får det her sin forklaring: det er et billede på den dåb og den genfødsel, der omtales i strofe 5. Genfødslen i Kristus forudsætter, at vi er Guds børn med Adam. Grundtvig havde et skabelsessyn og en missionsteologi, der helt sprænger rammerne for, hvad der findes $\mathrm{i}$ Montgomery's salme.

\section{VIII}

Som strofe 5's hovedmotiv er genfødslen, menneske- og kristenlivets fornyelse, er hovedmotivet i strofe 6 genløsningen, helliggørelsen (se ovenfor). Motivet anslås i de første ord i strofen, "Saligheds Fryd". Samtidig fastholdes genløsningen, helliggørelsen i sin dualistiske spænding, idet fortabelsens mulighed, og realitet! - sættes op overfor saligheden og genløsningen. Denne opfattelse var Grundtvigs egen, ligesom han genfandt den i de gamle angelsakseres kristendomssyn. Det var derfor naturligt for ham at komme ind på spørgsmålet $\mathrm{i}$ en af sine samtaler med den engelske præst i Helsingør, Nugent Wade, ${ }^{18}$ som han havde lært at kende som en repræsentant for det bedste i engelsk kirkeliv.

Den 26. februar 1835 var Nugent Wade sammen med Grundtvig i København, og de har ved den lejlighed talt om Kristi andet komme og de tegn, der vil gå forud herfor, bl.a. Antikrists komme. Nugent Wade noterer i sin dagbog, at "Antichrist he considers rationalism as set up in plan of or by Christ - " og han tilføjer i en parentes: "See his sermon on it", d.v.s. prædikenen "Avinds-Manden og Djævle-Skabet" i Søndagsbogens bind 3 fra $1831 .{ }^{19}$ Der kan være en forbindelse mellem netop denne samtale 
og Grundtvigs gendigtning af "O Spirit of the living God", da meget taler for, at Grundtvig har sin tekst til den engelske salme fra et eksemplar af The Christian Psalmist 3. udg. 1826 (1. udg. 1825) af James Montgomery, som Nugent Wade har ejet, og som han gav Grundtvig ved afrejsen fra Danmark den 4. april 1839. ${ }^{20}$

Grundtvig begynder prædikenen fra 1831 med at konstatere, at da det hører til dåbspagten at forsage Djævelen, er det ikke muligt at påstå, at der ikke er nogen Djævel til; videre mener han, at da Gud er sandhed, og Djævelen er Guds modstander, må følgelig alt, der er "lognagtigt eller uchristeligt" anses for "Djævelens Gierning og Væsen" (s. 231) og opleves som "Syndens og Dødens og Fortabelsens bundløse Afgrund " (s. 232). Længere henne i prædikenen kalder Grundtvig Kristus "Frelseren ..., der i Sandhed kan og vil udfrie os fra Satans Magt, forlige os med Gud, og føre os tilbage til Paradiset vi forbrød " (s. 237).

Grundtvig polemiserer prædikenen igennem mod rationalisterne, "de Selv-Kloge«, og en central, måske den centrale anklage mod dem er, at de bespotter Ånden. ${ }^{21}$ Derfor må Grundtvig indtrængende opfordre "os Christne" til ikke alene at "troe og bekiende, at der er en Djævel til, som skal forsages ", men også til sandhedskærligt at "bekrige og bestride hans falske, løgnagtige Væsen ", mens "de Selv-Kloge bespotte Sandhed, og, naar de virkelig veed, hvad de sige, bespotte den Hellig-Aand, til evig Fortabelse, ved at nægte Guds Fiendes Tilværelse, og saaledes giøre Gud selv til en Beelzebub: til Løgnens Fader, Hovmodens Aand, sin egen og Menneskeslægtens Avinds-Mand" (s. $242 \mathrm{f}$ ).

Dernæst kommer Grundtvig, ligesom i Kristi Himmelfartsprædikenen 1837, ind på den fristelse, som kristne mennesker kun alt for let bukker under for, nemlig fristelsen til at se bort fra "det svaelgende Dyb mellem Sandhed og Logn, som mellem Himmerig og Helvede, mellem Herren og hans Avinds-Mand, mellem Gud og Satan“ (s. 244). Der er, siger Grundtvig, ingen undskyldning for at se bort fra denne uoverstigelige forskel mellem Gud og Djævel, for selv den ikke-kristne ved, takket være "det Guddoms-Lys, der skinner selv i Hedenskabets tykkeste Mørke, skiøndt Mørket ei fatter det: at hvem der giver Sandheden sit Ja, giver Lognen sit Nei, hvem der giver Jaet Medhold, giver Neiet Afslag" (s. 245). Grundtvig kender sig selv og sine tilhørere godt 
nok til at vide, at "det er det ømme Sted, jeg her berører, thi denne er en af de haarde Taler, ved hvilken Mange vende Herren Ryggen, fordi de under ingen Omstændigheder vil bryde overtvert med Kiødet og Verden; men jeg maa sige: lad dem fare, de er ikke af Sandhed, ellers hørde de Herrens Røst, de er ikke af Gud, ellers bøiede de sig for hans Ord, selv naar det sønderknuser, de har i Grunden aldrig troet paa Jesus Christus som den levende Guds Søn, med det evige Livs Ord" (s. 246). Det er som om Grundtvig her foregriber sammenhængen mellem "Menneskens Kiøn " i strofe $1 \mathrm{og}$ "Fortabelsens Æt " i strofe 6 i »Du, som går ud fra den levende Gud ".

At denne polemik mod de "Selv-Kloge" ikke kun var et indlæg i en teologisk debat på akademisk plan om et tilfældigt dogmatisk problem, viser bl.a. nogle bemærkninger i Grundtvigs anmeldelse af P.A. Fengers udgave fra 1827 af Thomas Kingos Psalmer og aandelige Sange. ${ }^{22}$ Her kommer han i anledning af Evangelisk-kristelig Psalmebogs bearbejdelse af Luthers "Vor Gud han er så fast en borg " ind på, hvorfor man i denne salmebog, der var fra 1798 og stærkt præget af oplysningstidens og rationalismens tankegang, ønskede at se bort fra enhver tale om Djævel og Helvede. Det gjorde man, skriver Grundtvig, „for ei at giøre Djavelen vreed, thi uagtet man tit i de gamle Psalmebøger med Grund kunde ønske lidt mindre om Helvede, og lidt meer om Himmerig, saa er det dog alt fot latterligt at undsige Djævelen ved Daaben, som Kirkens og Christendommens farligste Fjende, og derpaa, under hele Kirkegangen, at lade, som om han aldrig var til, og naar vi tie kvær om Ormen som aldrig døer, og Ilden som ingen udslukker, da er det ikke Jesu Talebrug vi efterligne! « Denne fortrængning af Djævelen og Helvede lader sig, fortsætter Grundtvig, hverken forene "med vor Daabs-Pagt, eller med vor Bibel, eller med den christelige Erfaring gjennem alle Aarhundreder, at man kan ignorere Djævel og Helvede, uden netop derved at have dem idelig paa Halsen, og være hardtad vaabenløs imod dem! " Spørgsmålet om Djævelens og Helvedes virkelighed er ikke kun et akademisk spørgsmål, det er folkeligt, eksistentielt og i allerhøjeste grad aktuelt både for den, der skriver salmer eller redigerer en salmebog, og for dem, der skal synge salmerne. Det er efter Grundtvigs opfattelse et rimeligt og nødvendigt krav til en salme og en salmebog, at den 
beskriver virkeligheden, sådan som den er, og til virkeligheden hører, mener han, både Djævel og Helvede.

Noget andet er, hvor meget man skal gøre ud af den side af virkeligheden, som Djævelen og Helvede repræsenterer. Det er et spørgsmål, som Grundtvig kommer ind på i forbindelse med "Du, som går ud fra den levende Gud ", nemlig da han 1. søndag efter Trinitatis 1837 skulle prædike over lignelsen om Den rige mand og Lazarus (Luk. 16,19-31). Grundtvig skriver i denne prædiken, ${ }^{23}$, at "Stundom har jeg saaledes været tvivlraadig om, hvorvidt det var rigtigt, at jeg taler saa sjelden og saa lidt om Djavelen og Helvede" (s. 3). I sådanne situationer har Grundtvig svaret sig selv, at Jesus selv og hans disciple i grunden har talt forbavsende lidt om netop Djævelen og Helvede, "og naar jeg nu tænker efter, hvad Grunden dertil kan være», fortsætter han, "da finder jeg det ligesaa rimeligt, som det er glædeligt, thi ligesom Sønnen kom ikke for at dømme men for at frelse Verden, saaledes er det heller ikke en Trældoms Aand til Frygt men Barnlighedens Aand Gud-Fader i Jesu Navn har udøst over os, saa det er rimeligt nok at Han taler kun om Døden for at trøste os over den og om Helvede for at vogte os for det, men om Livet og Himlen, for at skabe og uddanne dem hos os $\mathrm{i}$ hele deres yndige og glædelige Skikkelse" (s. 4).

Iøvrigt vil det efter Grundtvigs opfattelse også være pædagogisk forkert at tale for meget om Djævelen og Helvede, for "det er soleklart, at det er ikke de Vantroe men de Troende som skiælve for Helvede, ikke Djævelens Venner men Hans Fiender, som forskrækkes ved Tanken om at ledes af ham, og ved at tale tit og meget om Djævel og Helvede, begaae vi da den samme store Feil, som vi ogsaa i det daglige Liv kun er alt for tilbøielige til, over de Fremmede, der ikke bryde sig om os, at glemme vore Egne, som lide med os, og medens vi arbeide os trætte paa at frelse dem fra Helvede, der enten slet ikke mærke det eller lee kun derad, glemme vi at føre dem til Himlen, der gierne vilde følge os paa saa glædelig en Vei, som Gud, trods al Fiendens Vold og List, har banet for os, da Han gav os sin eenbaarne Søn, som er Selv baade Veien og Sandheden og Livet" (s. 5).

Grundtvig har som enhver anden alvorlig kristen haft personlige oplevelser af Djævelens og Helvedes virkelighed; han kan her have tænkt på f.eks. oplevelsen i Vindbyholt Kro i 1810. Det 
er oplevelser, der må farve enhver alvorlig kristen tale: "Saaledes skal Menigheden høste Frugt af det levende Bekiendtskab vi kan have gjort med Djævel og Helvede, enten for vore grove Synders eller for vort hellige Embedes Skyld, og vi maa ingenlunde misbruge det til at forskrække de Smaa, der troe paa Herren, som om de hvert Øieblik var udsatte for Djævelens listige Anløb, bestandig i Fare for at gaae Glip ad Himlen og synke i Helvedes Afgrund, thi det strider baade mod Sandhed og Kiarlighed “ (s. 7). Den kristne, også den kristne prædikant, skal være sandheden tro i kærlighed, sådan som Grundtvig ønskede at være det, og var det, når han prædikede og når han skrev sine salmer.

"Du, som går ud fra den levende Gud" er et godt eksempel på, hvordan Grundtvigs salmer er blevet til i sammenhæng med alt, hvad han tænkte og talte, mens han skrev dem. Samtidig viser "Du, som går ud fra den levende Gud ", at det er i salmerne, som i digtningen iøvrigt, Grundtvigs tanker og følelser finder deres afklarede udtryk. I salmerne oplevede Grundtvig den dramatiskliturgiske enhed med Gud og mennesker og dermed med sig selv, som hans prædikener, hans kirkelige og teologiske prosa iøvrigt og hans bibellæsning førte frem til, men ikke i sig selv kunne virkeliggøre. Det spiller i denne forbindelse ingen rolle, om salmen er Grundtvigs egen, eller om den som "Du, som går ud fra den levende Gud " er en gendigtning efter et fremmed forlæg. Grundtvig gør gennem gendigtningen salmen til sin, og en sammenligning med forlægget viser kun, hvor overlegent selvstændig han var i sin salmedigtning.

\section{Noter}

1 N.F.S. Grundtvig: Anmeldelse af "Høimesse-Psalmer til Kirkeaarets Helligdage af B.S. Ingemann. Kbh. 1825 hos A. Seidelin S. 130. 8. " i Theologisk Maanedsskrift Bd. 3, s. 162 , Kbh. 1825.

2 N.F.S. Grundtvigs udkast til en anmeldelse af B.S. Ingemanns Høimesse-Psalmer 1825, s. 4 (Grundtvig-arkivet, Kgl. Bibl. Kbh. fasc. 116 I), se Hymnologiske Meddelelser 1983/1 s. 3-56, spec. s. 54.

3 N.F.S. Grundtvig: Anmeldelse af "Psalmer og aandelige Sange af Thomas Kingo, samlede og udgivne af P.A. Fenger, Præst, Kjøbenhavn 1827«i Theologisk Maanedsskrift Bd. 13, s. 16, Kbh. 1828.

4 Sang-Varket Bd. 1 nr. 243. 
5 Christelige Prodikener eller Sondags-Bog af Nik. Fred. Sev. Grundtvig Ordets Tjener. Bd. 3 Kbh. 1830, "Christi Nedfart til Helvede", s. 203-226, især s. $222 \mathrm{ff}$.

6 Chr. Ludwigs Af Menighedens Sang (Salme og Sang II), Kbh. 1918, s. 77-79.

7 Anf. skr. s. 78.

8 Første gang påvist af Lise Helweg i "Til Glæde for Graad - Om V - strukturen i Grundtvigs "håbssalme", For sammenhangens skyld, (Grundtvig-Studier 1977-78) Kbh. 1978, s. 247-259.

9 Hans Martensen Af mit Levnet. Bd. 2, Kbh. 1883, s. 50.

10 Peter Balslev-Clausen: "Tag det sorte kors fra graven ", Organist-bladet 1983/4, s. 139 f.

$11 \mathrm{Sml}$. salmen "Hyggelig, rolig", hvor det hedder, at "Sjælen af by over Stjernerne foer" (Sang-Varket, bd. 1, nr. 61.6:8).

12 Chr. Ludwigs, anf. skr. s. 79-82.

13 Anf. skr. s. $82 \mathrm{f}$.

14 Anders Malling Dansk salme-historie bd. 1, Kbh. 1962, s. 299.

15 Forestillingen er oldkirkelig og repræsenterer en apokryf tradition, sml. Nikodemusevangeliet (Pilatus-akterne) fra det 4. årh., der både har sammenstillingen af Livets træ med korset og en fremstilling af Kristi nedfart til dødsriget.

16 Se f.eks. Lexikon der christlichen Ikonographie, Freiburg 1968 f., artiklen "Rose" (af R. Schumacher-Wolfgarten). Sml. Helge Toldberg Grundtvigs symbolverden, Kbh. 1950, s. $38-41$.

17 Grundtvig-arkivet, Det kgl. Bibliotek, København, fasc. 26. Sidetal henviser til siden i manuskriptet til hver enkelt søndags prædiken.

18 Helge Toldberg: „Nugent Wade i Helsingør. En engelsk præsts møde med Grundtvig og Mynster" i Grundtvig-Studier 1948, Kbh. 1948, s. 50 f.

19 N.F.S. Grundtvig, anf. skr. s. $227 \mathrm{ff}$.

20 Anders Malling, anf. skr. s. $297 \mathrm{f}$.

21 Prædiketeksten er Matth. 12,22-37, hvor v. 31 lyder i den oversættelse, Grundtvig aftrykker før selve prædikenen: "Al anden Synd og Bespottelse skal Menneskene forlades, men Aands-Bespottelsen skal ikke forlades Menneskene", s. $227 \mathrm{f}$.

22 N.F.S. Grundtvig, anf. skr. Se Peter Balslev-Clausen: "Salmebog og salmesang", Hymnologiske Meddelelser 1983/1, s. 3ff, spec. s. 20.

23 Grundtvig-arkivet fasc. 26. (se note 17). 